Estructura por tallas, sexo y estadios de madurez de la corvina blanca (Micropogonias furnieri, Desmarest, 1823; Teleostei: Sciaenidae), captura incidental en la pesquería artesanal en Laguna de Rocha, Uruguay

\title{
Structure by size, sex and maturity stage of the white croaker (Micropogonias furnieri, Desmarest, 1823; Teleostei: Sciaenidae) in the bycatch of the artisanal fishery at Rocha Lagoon, Uruguay
}

\author{
Gustavo Saona ${ }^{1 *}$ \\ Florencia Forni ${ }^{2}$ \\ Denise Vizziano ${ }^{1}$ \\ Walter Norbis ${ }^{1}$ \\ ${ }^{1}$ Departamento de Ecología \\ Facultad de Ciencias \\ Universidad de la República \\ Iguá 4227, Montevideo, CP 11400, Uruguay \\ *E-mail: saona@netgate.com.uy \\ ${ }^{2}$ PROBIDES \\ Ruta 9, 204 km, Rocha, Uruguay \\ Recibido en mayo de 2002; aceptado en mayo de 2003
}

\section{Resumen}

Se analizó la estructura de la población de corvina blanca (Micropogonias furnieri) capturada de manera incidental en la pesquería artesanal y multiespecífica de Laguna de Rocha, Uruguay. La especie, que es el segundo recurso pesquero en Uruguay, ha sido declarada plenamente explotada y existen pocos estudios sobre su pesca artesanal y sobre su biología, como pez que habita en las lagunas costeras uruguayas. Las corvinas blancas se obtuvieron como fauna acompañante de cinco pesquerías de distintas especies objetivo que operan en diferentes zonas de la laguna. Los cinco artes de pesca analizados (con apertura de malla de 1, 2, 4, 10 y $20 \mathrm{~cm}$ ) capturaron distintas fracciones de la estructura por tallas, sexos y estadios de madurez. La mediana y el primer cuartil de la composición de tallas retenidas por cada uno de los artes de pesca fueron mayores que la talla de primera madurez. En este trabajo se muestra el efecto de diferentes modalidades de pesca artesanal sobre la estructura de la población de la corvina blanca y provee información básica que puede utilizarse para la conservación y manejo de uno de los recursos pesqueros cuyo hábitat forma parte de un Parque Nacional dentro de la Reserva de la Biosfera Bañados del Este de la MAB/ UNESCO.

Palabras clave: pesquería artesanal, captura incidental, Micropogonias furnieri, selectividad, segregación espacial.

\begin{abstract}
The structure of the population of white croaker (Micropogonias furnieri), a bycatch species of the multi-specific artisanal fishery at the coastal lagoon of Rocha, was analyzed. This species is Uruguay's second fishery resource and it has been declared fully exploited. Few data are available on the artisanal fishery and the biology of this fish, which inhabits the Uruguayan coastal lagoons. The white croakers were obtained from the bycatch of five fisheries that target diverse species in different parts of the lagoon. The five net types studied (mesh sizes 1, 2, 4, 10 and $20 \mathrm{~cm}$ ) caught different fractions of the structure per size, sex and maturity stage. Both the median and first quartile of the size composition retained by each net size were bigger than the size at first maturity. This work shows the effect of different kinds of artisanal fishery on the structure of the white croaker population and provides basic information for the conservation and management of one of the fishery resources whose habitat forms part of the national park within the MAB/UNESCO Bañados del Este Biosphere Reserve.
\end{abstract}

Key words: artisanal fishery, bycatch, Micropogonias furnieri, selectivity, spatial segregation. 


\section{Introducción}

La corvina blanca (Micropogonias furnieri, Desmarest, 1823) se distribuye desde la Península de Yucatán (México) hasta Bahía Blanca (Argentina) (Isaac-Nahum, 1988). En el Atlántico sudoccidental es uno de los principales recursos pesqueros y se captura por las flotas de pesca costeras de Uruguay, Brasil y Argentina (Arena, 1990; Haimovici, 1998). En Uruguay y Argentina se declaró especie plenamente explotada.

Sobre la costa sudeste de Uruguay existe un sistema de lagunas (Laguna de José Ignacio, Laguna de Garzón, Laguna de Rocha, Laguna de Castillo, Laguna Negra y Laguna Merín) que son consideradas zonas de alimentación y cría de peces marinos (Conde y Sommaruga, 1999; Santana y Fabiano, 1999; fig. 1). De éstas, Laguna de Rocha se considera un área de reproducción para la corvina blanca (Vizziano et al., 2002), mientras que en las lagunas de José Ignacio, Rocha y Castillo la corvina se captura de manera incidental como fauna acompañante de especies que son objeto de distintas pesquerías (tabla 1).

El conocimiento de la dinámica del stock pescable necesita de la estimación de los parámetros de la población de peces que son seleccionados por el arte de pesca (Csirke, 1980; Millar y Fryer, 1999; Lucena y O’Brien, 2001). Los artes de enmalle presentan un importante grado de selección de tamaños, siendo contorno-específicas (Reis y Pawson, 1999). En general, para los peces, el contorno es directamente proporcional al largo y, si el crecimiento es isométrico, permite el uso de la talla en la descripción de la selectividad del arte (Reis y Pawson, 1999). La estimación de los parámetros de la población también depende de la representatividad de las muestras, las que pueden estar influidas por los movimientos de las distintas fracciones de la población en el área de distribución de la especie, así como por la selectividad del arte (Lucena y O’Brien, 2001). Como consecuencia de los movimientos reproductivos se pueden producir agregaciones de peces con distinta proporción de individuos maduros o inmaduros que presentan diferentes estructuras de talla (Haimovici y Umpierre, 1996; Sampson y Al-Jufaily, 1999).

En el presente trabajo se estudió la estructura de la población (talla, sexo y estadios de madurez sexual) de la corvina blanca (de septiembre de 1997 a febrero de 1999) que se captura incidentalmente por la pesquería artesanal y multiespecífica que opera en Laguna de Rocha.

\section{Materiales y métodos}

La Laguna de Rocha se localiza en el litoral Atlántico uruguayo, dentro de la Reserva de la Biosfera Bañados del Este, y se ubica entre los $34^{\circ} 31^{\prime}-34^{\circ} 38^{\prime} \mathrm{S}$ y los $54^{\circ} 12^{\prime}-54^{\circ} 22^{\prime} \mathrm{W}$ (fig. 1). Posee un área de $72 \mathrm{~km}^{2}$ y una profundidad media de $0.58 \mathrm{~m}$ (Pintos et al., 1990; Sommaruga y Conde, 1990). Su

\section{Introduction}

The white croaker, Micropogonias furnieri Desmarest, 1823, occurs from the Yucatán Peninsula, Mexico, to Blanca Bay, Argentina (Isaac-Nahum, 1988). It is one of the main fishery resources in the southwestern Atlantic and is caught by the coastal fishing fleets of Uruguay, Brazil and Argentina (Arena, 1990; Haimovici, 1998). In Uruguay and Argentina it has been declared fully exploited.

The lagoons on the southeastern coast of Uruguay (José Ignacio Lagoon, Garzón Lagoon, Rocha Lagoon, Castillo Lagoon, Negra Lagoon and Merín Lagoon; fig. 1) serve as feeding and nursery grounds for several marine fishes (Conde and Sommaruga, 1999; Santana and Fabiano, 1999); of these, Rocha Lagoon is considered a spawning area for the white croaker (Vizziano et al., 2002). The white croaker is caught incidentally as bycatch of species targeted by diverse fisheries at the lagoons of José Ignacio, Rocha and Castillo (table 1).

To know the dynamics of the available stock it is necessary to estimate the parameters of the fish populations selected by the fishing gear (Csirke, 1980; Millar and Fryer, 1999; Lucena and O'Brien, 2001). Gillnets are highly selective gear, as they are size-specific (Reis and Pawson, 1999). In general, for fishes, the girth is directly proportional to the length and if the growth is isometric, the size in the description of the gear selectivity can be used (Reis and Pawson, 1999). Estimation of population parameters depends on the representativity of the

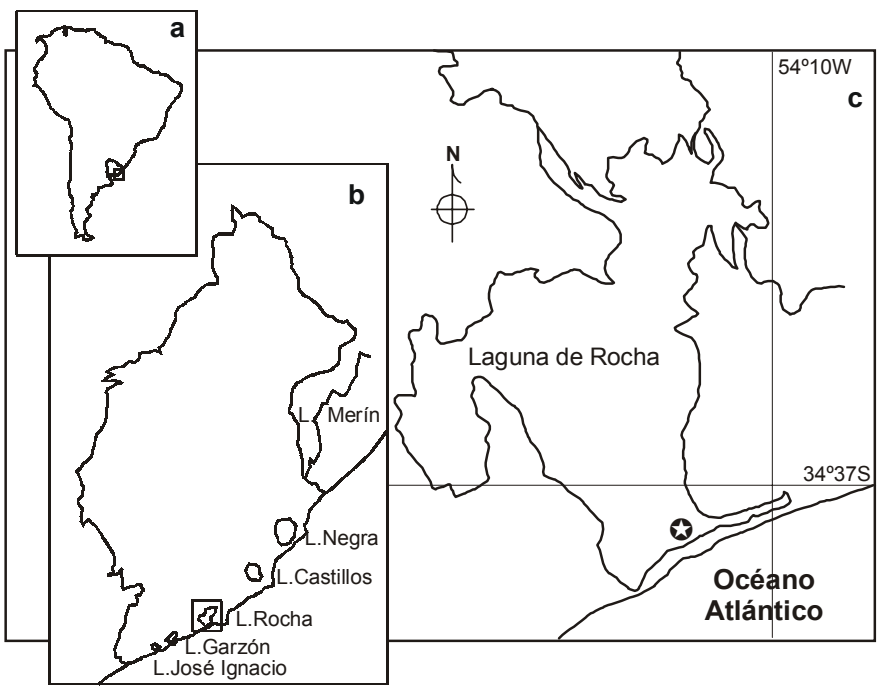

Figura 1. (a) Ubicación de Uruguay en Sudamérica. (b) Reserva de Biosfera Bañados del Este, con el sistema de lagunas costeras uruguayo: Laguna de José Ignacio, Laguna de Garzón, Laguna de Rocha, Laguna de Castillo, Laguna Negra y Laguna Merín. (c) Laguna de Rocha; ( $*$ punto de pesca de la red de playa para camarón (A1).

Figure 1. (a) Location of Uruguay in South America. (b) Bañados del Este Biosphere Reserve, with the system of coastal lagoons: Laguna de José Ignacio, Laguna de Garzón, Laguna de Rocha, Laguna de Castillo, Laguna Negra and Laguna Merín. (c) Laguna de Rocha; ( $*$ ) fishing area of the beach seine for shrimp (A1). 
Tabla 1. Artes de pesca analizadas y sus especies objetivo. Las artes se identifican empleando la nomenclatura y código propuestos por FAO (Nédélec y Prado, 1990). El tamaño de malla se midió entre nudos opuestos.

Table 1. Fishing gear analyzed and their target species. The gear are identified using the nomenclature and codes proposed by FAO (Nédélec and Prado, 1990). The mesh size was measured between opposite knots.

\begin{tabular}{|c|c|c|c|c|}
\hline Arte de pesca* & Código & $\begin{array}{l}\text { Longitud de la } \\
\quad \text { red }(\mathrm{m})\end{array}$ & $\begin{array}{l}\text { Tamaño de } \\
\text { malla }(\mathrm{cm})\end{array}$ & Especie objetivo \\
\hline A1: Red de playa & 02.1 .0 & 200 & 1 copo & Camarón (Penaeus paulensis, Pérez-Farfante, 1967) [shrimp] \\
\hline A2: Red de playa & 07.3 .0 & 400 & 2 & $\begin{array}{l}\text { Pejerrey (Odonthestes argentinensis, Valenciennes, 1835) } \\
\text { [silverside] }\end{array}$ \\
\hline A4: Enmalle de cerco & 07.3 .0 & 600 & 4 & Lisa (Mugil platanus, Günther, 1880) [mullet] \\
\hline A10: Enmalle calada & 07.1 .0 & $400-500$ & 10 & Lacha (Brevoortia aurea, Agassiz, 1829) [menhaden] \\
\hline A20: Enmalle calada & 07.1 .0 & 1200 & 20 & $\begin{array}{l}\text { Lenguado (Paralichthys orbignyanus, Valenciennes, 1839) } \\
\text { [flatfish] }\end{array}$ \\
\hline
\end{tabular}

${ }^{*} \mathrm{~A} 1, \mathrm{~A} 2$ = beach seine; $\mathrm{A} 4$ = encircling gillnets; $\mathrm{A} 10, \mathrm{~A} 20$ = set gillnets.

barra se abre periódicamente al Océano Atlántico en forma natural o artificial.

En este lugar se estudiaron las corvinas capturadas como fauna acompañante en las pesquerías de cinco distintas especies objetivo que operan sobre distintas zonas de la laguna (fig. 1; tabla 1). De cada pez se registraron longitud total $(0.1 \mathrm{~cm})$ y sexo, y para la determinación del estadio de madurez sexual se tomaron como base los estudios de Vizziano et al. (2002): E1, inmaduro y en maduración; E2, maduración avanzada, desovante y desovado; y E3, reposo. Las características de los artes de pesca correspondientes a cada pesquería y la apertura de malla se presentan en la tabla 1, empleando la nomenclatura y códigos de FAO (Nédélec y Prado, 1990). El tamaño de malla se midió entre nudos opuestos. Las pesquerías de camarón y pejerrey se realizan desde la costa con la ayuda de un bote. En la pesquería del camarón, la red de playa se ha sustituido por trampas y en este estudio se instrumentó su uso con una frecuencia semanal de noviembre de 1997 a junio de 1998, quincenal de julio a noviembre de 1998 y prosiguió semanalmente hasta febrero de 1999. La pesca de lisa se realiza en bote y encerrando el cardumen. En las pesquerías de lacha y lenguado las redes son caladas fijas y recorridas por el pescador cada 12 o 24 horas. Las recolectas de estas últimas artes de pesca comenzaron en septiembre de 1997 y fueron ocasionales ya que la actividad de las pesquerías es afectada por la disponibilidad del recurso y la demanda de mercado. Para detectar cambios temporales en la estructura de la población, la información se agrupó por mes excepto en la pesquería del lenguado, ya que en ella los datos son insuficientes. La hipótesis de igual proporción de sexos se contrastó a través del estadístico de Ji-cuadrado $\left(\chi^{2} ; \alpha=0.05\right)$ (Zar, 1996). Para la comparación de las distribuciones de tallas, agrupadas al centímetro inferior, se utilizó la prueba de KolmogorovSmirnov $(\alpha=0.05)$ (Zar, 1996), la misma que se aplicó entre artes y fechas de manera secuencial. samples, which can be influenced by the movements of the different fractions of the population as well as by the selectivity of the gear (Lucena and O'Brien, 2001). As a result of breeding migrations, fish assemblages can occur with a different proportion of mature and immature individuals that have different size structures (Haimovici and Umpierre, 1996; Sampson and Al-Jufaily, 1999).

The purpose of this work is to study the structure of the population (size, sex and maturity stage) of the white croaker that is caught as bycatch in the multi-specific artisanal fishery that operates in Rocha Lagoon (September 1997 to February 1999)

\section{Material and methods}

Rocha Lagoon is located on the Atlantic coast of Uruguay $\left(34^{\circ} 31^{\prime}-34^{\circ} 38^{\prime} \mathrm{S}, 54^{\circ} 12^{\prime}-54^{\circ} 22^{\prime} \mathrm{W}\right)$, within the Bañados del Este Biosphere Reserve (fig. 1). It covers an area of $72 \mathrm{~km}^{2}$ and has a mean depth of $0.58 \mathrm{~m}$ (Pintos et al., 1990; Sommaruga and Conde, 1990). The mouth opens periodically, either naturally or artificially, to the Atlantic Ocean.

The white croakers were obtained from the bycatch of five multi-species fisheries that operate in different parts of the lagoon (fig. 1; table 1). The total length $(0.1 \mathrm{~cm})$ and sex of each fish was recorded, and the sexual maturity stage was determined according to Vizziano et al. (2002): E1, immature and in maturation; E2, advanced maturation, spawning and spawned; and E3, repose. The characteristics of the fishing gear employed in each fishery are given in table 1, using the FAO codes and nomenclature (Nédélec and Prado, 1990); the mesh size was measured between opposite knots. The shrimp and silverside fisheries are conducted from the coast using a boat. In the shrimp fishery, the beach seine has been substituted by traps, and in this study they were used weekly from November 1997 to June 1998, fortnightly from July to November 1998, and then weekly until February 1999. The mullet fishery 
Tabla 2. Estadísticos descriptivos de la talla (centímetros) de la corvina Micropogonias furnieri capturada por arte de pesca para los lances analizados. La prueba de Kolmogorov-Smirnov mostró diferencias significativas entre medianas por arte $(\mathrm{Q} 1=$ primer quartil; $\mathrm{Q} 3=$ tercer quartil; CV = coeficiente de variación). La proporción de hembras $(\mathrm{H} \%)$ fue significativamente mayor para las artes cuyas especies objetivos son la lisa y la lacha (ds: diferencias significativas; ns: no significativas; $\alpha=0.05$ ).

Table 2. Descriptive statistics of the size (centimeters) of the croaker Micropogonias furnieri caught per fishing gear for the sets analyzed. The KolmogorovSmirnov test showed significant differences between medians per gear $(\mathrm{Q} 1=$ first quartile; $\mathrm{Q} 3=$ third quartile; $\mathrm{CV}=$ coefficient of variation). The proportion of females $(\mathrm{H} \%$ ) was significantly greater for the gear whose target species are mullet and menhaden (ds: significant differences; ns: not significant; $\alpha=0.05)$.

\begin{tabular}{cccccccccccc}
\hline $\begin{array}{c}\text { Arte } \\
(\mathrm{cm})\end{array}$ & $\begin{array}{c}\mathrm{N}^{\circ} \text { redes } \\
\text { analizadas }\end{array}$ & $\begin{array}{c}\mathrm{N}^{\mathrm{o}} \text { lances } \\
\text { analizados }\end{array}$ & $\begin{array}{c}\mathrm{N}^{\circ} \text { peces } \\
\text { analizados }\end{array}$ & Media & Mediana & Moda & Varianza & $\mathrm{CV}$ & $\mathrm{Q} 1$ & Q3 & $\mathrm{H} \%$ \\
\hline 1 & 2 & 36 & 2715 & 23.8 & $23.0 \mathrm{ds}$ & 23.0 & 16.2 & 17.0 & 21.0 & 26.0 & $50.7 \mathrm{~ns}$ \\
2 & 4 & 13 & 675 & 26.1 & $27.0 \mathrm{ds}$ & $22.0 \mathrm{y} 30.0$ & 30.2 & 21.0 & 22.0 & 30.0 & $52.6 \mathrm{~ns}$ \\
4 & 4 & 12 & 432 & 31.6 & $31.0 \mathrm{ds}$ & 30.5 & 7.9 & 8.9 & 30.0 & 33.0 & $61.8 \mathrm{ds}$ \\
10 & 4 & 6 & 73 & 32.7 & $32.0 \mathrm{ds}$ & $30.0 \mathrm{y} 38.0$ & 37.5 & 18.7 & 30.0 & 36.0 & $64.4 \mathrm{ds}$ \\
20 & 2 & 2 & 19 & 40.1 & $37.0 \mathrm{ds}$ & 35.0 & 49.5 & 17.6 & 34.0 & 44.0 & $52.6 \mathrm{~ns}$ \\
\hline
\end{tabular}

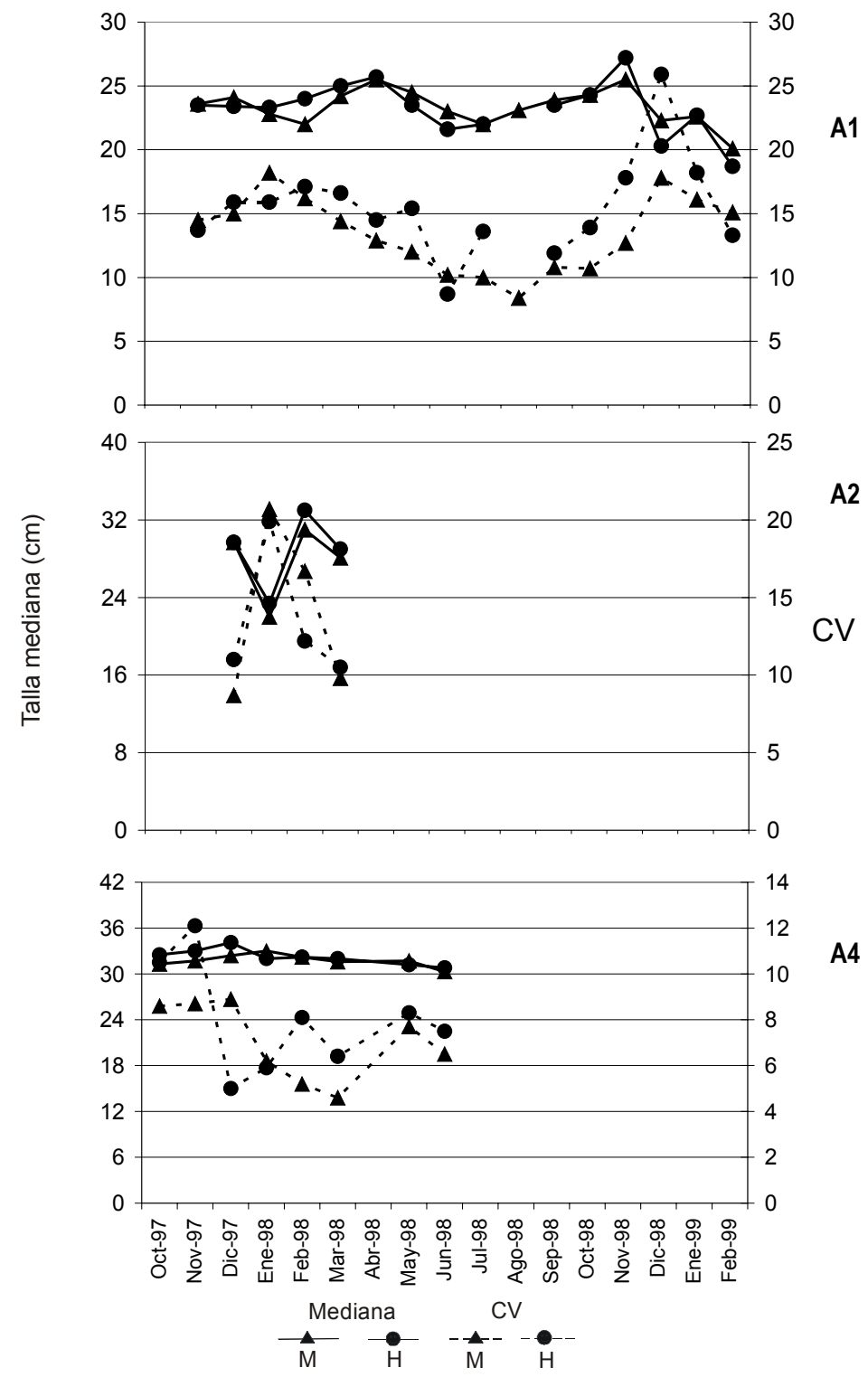

Figura 2. Evolución temporal de la mediana y el coeficiente de variación (CV) para la talla por sexo en la captura de la corvina blanca Micropogonias furnieri, para cada arte de pesca en la Laguna de Rocha: $\mathbf{A} 1$, malla de $1 \mathrm{~cm} ; \mathbf{A 2}$, malla de $2 \mathrm{~cm} ; \mathbf{A} 4$, malla de $4 \mathrm{~cm}$. $\mathrm{M}=$ machos; $\mathrm{H}=$ hembras.

Figure 2. Temporal evolution of the median and coefficient of variation (CV) for the size per sex in the catch of the white croaker Micropogonias furnieri, for each fishing gear at Rocha Lagoon: A1, 1-cm mesh size; A2, 2-cm mesh size; A4, 4-cm mesh size. $M=$ males; $H=$ females. 


\section{Resultados}

\section{Análisis de la estructura de la población por arte}

Las tallas de $M$. furnieri retenidas por los distintos artes fueron significativamente distintas $(P<0.05)$. La media y la mediana aumentaron con el incremento en la apertura de malla (tabla 2). Los valores modales de la distribución de tallas presentaron un importante grado de recurrencia entre los distintos artes y mostraron un cambio de distribuciones de unimodal a bimodal según la apertura de malla. Los valores extremos para tallas por arte fueron similares, con excepción del A20. El intervalo de tallas presentó una variación no relacionada con el incremento en el tamaño de malla (tabla 2). La varianza de la composición de tallas aumentó con el incremento de apertura de malla, con la excepción del A4 que presentó menores varianza y coeficiente de variación (CV) (tabla 2). En las capturas realizadas con los artes A4 y A10 predominaron Las hembras $(P<0.05)$ (tabla 2).

\section{Análisis temporal}

Red de playa para camarón (A1)

Las tallas medias y medianas mensuales fueron similares, con valores mayores en abril y noviembre de 1998 y mínimos en febrero de 1999. Los mayores valores del CV se presentaron en enero, febrero y diciembre de 1998 y en enero de 1999 (tabla 3). La evolución mensual de tallas medias y medianas, así como el $\mathrm{CV}$, siguen las mismas tendencias en ambos sexos (fig. 2). La proporción de hembras en las capturas superó significativamente el 50\% durante los meses de diciembre de 1997 a marzo de 1998 y en enero de 1999; el aumento en la proporción de hembras se acompañó por un aumento en el CV, y las capturas de individuos en estadio E1 superaron el $50 \%$ en los meses de julio a septiembre de 1998 y en febrero de 1999 (tabla 3).

\section{Red de playa para pejerrey (A2)}

La media y la mediana de la composición de tallas de M. furnieri, al igual que el CV, no presentaron patrón de variación temporal (tabla 3). Por sexos, la mediana y el CV mostraron tendencias similares (fig. 2). En 1998, las hembras predominaron en febrero y los machos en marzo. Se capturaron principalmente individuos en estadio E2 (tabla 3).

Red de enmalle de cerco para lisa (A4)

La media y la mediana de la composición de tallas de M. furnieri presentó un leve descenso hacia los meses de invierno (tabla 3). El CV mostró valores más bajos hacia los meses de diciembre de 1997, enero y marzo de 1998. Entre sexos la talla mediana y el CV siguen la misma evolución mensual (fig. 2). En la mayoría de los meses la proporción de is conducted from the boat, encircling the school of fish with gillnets. In the menhaden and flatfish fisheries, set gillnets are used and moved by the fisherman every 12 or 24 hours. These last samplings began in September 1997 and were occasional, since the activity of the fisheries is affected by the availability of the resource and market demand. To detect temporal changes in the structure of the population, the data were grouped by month, except in the case of the flatfish fishery because of insufficient information. The hypothesis of equal numbers of males and females was tested with the chi-square statistic $\left(\chi^{2} ; \alpha=0.05\right)$ (Zar, 1996). To compare the distribution of sizes, grouped to the lower centimeter, the KolmogorovSmirnov test was used $(\alpha=0.05)$ (Zar, 1996), which was applied sequentially between gear and dates.

\section{Results}

\section{Analysis of the population structure by gear}

The sizes of $M$. furnieri retained with the diverse fishing gear were significantly different $(P<0.05)$. The mean and median increased as the mesh size increased (table 2). The modal values of the size distribution presented an important degree of recurrence between the different gear and showed a change from unimodal distribution to bimodal distribution depending on mesh size. The extreme size values per gear were similar, except for A20. The variation in the range of sizes was not related to the increase in mesh size (table 2). The variation in size composition increased as the mesh size increased, except in the case of $\mathbf{A 4}$, which presented lower variance and coefficient of variation (CV) values (table 2). Females predominated $(P<0.05)$ in the $\mathbf{A 4}$ and $\mathbf{A 1 0}$ catches (table 2).

\section{Temporal analysis}

Beach seine for shrimp (A1)

The monthly mean and median sizes were similar, with the highest values in April and November 1998, and the lowest in February 1999. The highest CV values were obtained in January, February and December 1998, and January 1999 (table 3). The monthly evolution of the mean and median sizes as well as CV followed the same trend for both sexes (fig. 2). The proportion of females in the catches was well above $50 \%$ from December 1997 to March 1998 and in January 1999; the increase in the number of females was accompanied by an increase in $\mathrm{CV}$, and the number of individuals in stage $\mathrm{E} 1$ was more than 50\% from July to September 1998 and in February 1999 (table 3).

Beach seine for silverside (A2)

The mean and median of the size composition of $M$. furnieri did not present a pattern of temporal variation just as $\mathrm{CV}$ (table 3). The median and CV presented similar trends for 
hembras se encontró por encima del 50\% (tabla 3). Este arte presentó las capturas con menor proporción de individuos en E1 (tabla 3).

Red de enmalle calada para lacha (A10)

La media y la mediana de la composición de tallas de M. furnieri no mostraron una tendencia temporal, aunque si se observó que el CV aumentó de septiembre de 1997 a enero de 1998. La proporción de hembras aumentó entre los meses de septiembre y enero, siendo mayor al 50\% (tabla 3). Debido al bajo número de lances de pesca, y de peces registrados con esta red, no se analizaron los estadios de madurez y talla discriminada por sexo.

\section{Discusión}

Los artes de pesca utilizados para la captura de las distintas especies objetivo, aun con aperturas de malla similares, retuvieron corvinas blancas cuya estructura fue significativamente distinta. Se observó un aumento de las tallas medias y medianas, y un cambio de distribuciones unimodales a bimodales con el aumento de la apertura de malla. A pesar de que no se realizaron experimentos de selectividad (Millar y Fryer, 1999), el valor de la mediana indicó a que talla se retuvo el $50 \%$ de la población que es accesible al arte de pesca, y los valores modales permitieron identificar aquellos grupos de tallas que predominaron en la captura de cada arte. Además de la variación debida al tamaño de malla en la selectividad del arte, se encuentra el efecto de la distribución de los individuos, el cual provoca que algunos no estén disponibles para ciertos artes de pesca en el lugar que éstos se operan (Millar y Fryer, 1999). No se pudieron cubrir todos los meses ni tampoco se realizaron capturas simultáneas con los distintos artes en las mismas áreas. Esto impidió tener una apreciación más detallada del efecto temporal en los cambios de la estructura de la población debidos al movimiento de cardúmenes y a la segregación por tamaños de la población de corvina dentro de la laguna. Para diferenciar los efectos de la selectividad del arte de los movimientos de los distintos grupos de tallas se deberían realizar muestreos con los distintos artes en las mismas zonas.

La estructura de tallas de la corvina blanca presentó variaciones en los distintos meses. Al comienzo del período de muestreo (noviembre de 1997 a marzo de 1998) se observó un comportamiento opuesto entre tallas retenidas por la pesca dirigida al camarón y la lisa. Una explicación de ello puede darse con base en el desplazamiento de los individuos mayores desde la zona costera donde se operó con el arte de pesca del camarón (A1) hacia otras de mayor profundidad y menos costeras, donde se capturó lisa. Estos desplazamientos de grupos con diferentes tallas podrían invertirse según la época del año. La segregación espacial por grupos de tallas de M. furnieri se reporta para la especie dentro del Río de la Plata y el sur de Brasil (Ehrhardt et al., 1977; Ehrhardt et al., 1979; Cousseau et al., 1986; Sánchez et al., 1991; Haimovici y Umpierre, 1996). males and females (fig. 2). Females predominated in February and males in March 1998. Stage E2 individuals were the most abundant (table 3).

Encircling gillnet for mullet (A4)

The mean and median sizes of $M$. furnieri decreased slightly towards the winter months (table 3 ). The lowest CV values were obtained in December 1997, and in January and March 1998. The monthly evolution of the median size and CV was similar for males and females (fig. 2). The proportion of females was greater than $50 \%$ in most months (table 3 ). The fewest number of individuals in stage E1 were caught with this gear (table 3).

Set gillnet for menhaden (A10)

The mean and median of the size composition of $M$. furnieri did not show a temporal trend, though CV did increase from September 1997 to January 1998. The proportion of females increased from September to January and was greater than $50 \%$ (table 3). Due to the low number of fishing sets and fish recorded with this gear, neither the maturity stages nor size differentiated by sex were analyzed.

\section{Discussion}

The fishing gear employed to catch the different target species, even with similar mesh size, captured white croakers whose structure was significantly different. There was an increase in the mean and median sizes and a change from unimodal to bimodal distribution as the mesh size increased. Even though selectivity experiments were not conducted (Millar and Fryer, 1999), the median value indicated the size at which $50 \%$ of the population that is accessible to the gear was retained and the modal values revealed the predominant size groups in the catch of each gear. In addition to the variation due to mesh size in the selectivity of the gear, there is the effect of the distribution of the individuals, which results in their unavailability to some of the gear in the places where they are used (Millar and Fryer, 1999). As we were unable to cover all the months or to conduct simultaneous catches with the different gear in the same areas, it was not possible to obtain a more-detailed evaluation of the temporal effect on the changes in the population structure because of the movement of the shoals and the segregation by sizes of the population within the lagoon. To differentiate the effects of gear selectivity from the movements of the different size groups, samplings should be conducted with the different gear in the same areas.

The size structure of $M$. furnieri presented monthly variations. At the beginning of the sampling period (November 1997 to March 1998), a different behaviour was observed for the sizes retained in the fisheries that targeted shrimp and mullet. An explanation may be the movement of the larger individuals from the coastal zone, where the shrimp fishing 
Tabla 3. Estadísticos descriptivos para la talla de la corvina Micropogonias furnieri por mes y arte de pesca (apertura de malla 1, 2, 4, y $10 \mathrm{~cm}$ ), proporción de hembras (H\%) y proporción de estadios de madurez sexual (E1: inmaduro y en maduración; E2: maduración avanzada, desovante y desovado; E3: reposo). Resultados de la prueba Kolmogorov-Smirnov y de la prueba $\chi^{2}$ (ds: diferencias significativas; ns: no significativas; $\alpha=0.05$ ).

Table 3. Descriptive statistics for the size of the croaker Micropogonias furnieri per month and fishing gear (mesh size: 1, 2, 4 and $10 \mathrm{~cm}$ ), and proportion of females $(\mathrm{H} \%)$ and of sexual maturity stages (E1: immature and in maturation; E2: advanced maturation, spawning and spawned; E3: repose). Results of the Kilmogorov-Smirnov and $\chi^{2}$ tests (ds: significant differences; ns: not significant; $\alpha=0.05$ ).

\begin{tabular}{|c|c|c|c|c|c|c|c|c|c|c|}
\hline $\begin{array}{l}\text { Arte } \\
(\mathrm{cm})\end{array}$ & Fecha & $\mathrm{N}$ & Media & Mediana & $\mathrm{CV}$ & Intervalo & $\mathrm{H} \%$ & E1 & E2 & E3 \\
\hline 1 & Nov. 1997 & 241 & 24.1 & $23.0 \mathrm{ds}$ & 14.5 & $18.8-36.7$ & $49.8 \mathrm{~ns}$ & 15 & 85 & 0 \\
\hline 1 & Dic. 1997 & 94 & 24.2 & $23.0 \mathrm{ds}$ & 15.6 & $17.6-35.3$ & $69.1 \mathrm{ds}$ & 9 & 91 & 0 \\
\hline 1 & Ene. 1998 & 195 & 23.3 & $23.0 \mathrm{ds}$ & 17.3 & $13.8-37.2$ & $62.6 \mathrm{ds}$ & 13 & 87 & 0 \\
\hline 1 & Feb. 1998 & 348 & 24.2 & $23.0 \mathrm{ds}$ & 17.6 & $15.4-46.0$ & $91.1 \mathrm{ds}$ & 18 & 82 & 0 \\
\hline 1 & Mar. 1998 & 324 & 25.0 & $24.0 \mathrm{ds}$ & 16.0 & $15.7-41.5$ & $56.8 \mathrm{ds}$ & 8 & 92 & 0 \\
\hline 1 & Abr. 1998 & 208 & 25.0 & $25.0 \mathrm{ds}$ & 14.4 & $14.1-34.5$ & $30.4 \mathrm{ds}$ & 26 & 42 & 32 \\
\hline 1 & May. 1998 & 169 & 24.3 & $24.0 \mathrm{ds}$ & 13.1 & $16.5-36.0$ & $18.3 \mathrm{ds}$ & 17 & 1 & 82 \\
\hline 1 & Jun. 1998 & 98 & 22.7 & $22.0 \mathrm{ds}$ & 10.6 & $18.4-29.0$ & $14.3 \mathrm{ds}$ & 27 & 0 & 73 \\
\hline 1 & Jul. 1998 & 44 & 22.2 & $21.5 \mathrm{ds}$ & 11.0 & $19.5-31.2$ & $13.6 \mathrm{ds}$ & 75 & 0 & 25 \\
\hline 1 & Ago. 1998 & 24 & 22.7 & $22.5 \mathrm{ds}$ & 8.2 & $20.1-27.2$ & $4.2 \mathrm{ds}$ & 83 & 0 & 17 \\
\hline 1 & Sep. 1998 & 199 & 23.5 & $23.0 \mathrm{ds}$ & 11.3 & $17.2-35.1$ & $27.6 \mathrm{ds}$ & 58 & 31 & 11 \\
\hline 1 & Oct. 1998 & 120 & 24.4 & $24.0 \mathrm{ds}$ & 12.5 & $20.2-40.7$ & $45.0 \mathrm{~ns}$ & 33 & 64 & 3 \\
\hline 1 & Nov. 1998 & 105 & 26.0 & $25.0 \mathrm{ds}$ & 16.0 & $17.8-38.8$ & $46.7 \mathrm{~ns}$ & 16 & 81 & 3 \\
\hline 1 & Dic. 1998 & 270 & 21.6 & $21.0 \mathrm{ds}$ & 22.3 & $12.2-41.1$ & $46.3 \mathrm{~ns}$ & 36 & 64 & 0 \\
\hline 1 & Ene. 1999 & 189 & 22.4 & $22.0 \mathrm{ds}$ & 17.9 & $15.3-33.4$ & $66.1 \mathrm{ds}$ & 33 & 67 & 0 \\
\hline 1 & Feb. 1999 & 58 & 19.1 & $19.0 \mathrm{ds}$ & 15.3 & $13.6-27.1$ & $56.9 \mathrm{~ns}$ & 71 & 29 & 0 \\
\hline 2 & Dic. 1997 & 188 & 29.0 & $29.0 \mathrm{ds}$ & 10.2 & $22.5-43.5$ & $52.7 \mathrm{~ns}$ & 3 & 96 & 1 \\
\hline 2 & Ene. 1998 & 365 & 23.1 & $22.0 \mathrm{ds}$ & 20.9 & $13.8-42.0$ & $50.7 \mathrm{~ns}$ & 33 & 67 & 0 \\
\hline 2 & Feb. 1998 & 63 & 33.6 & $32.0 \mathrm{ds}$ & 13.2 & $29.0-49.5$ & $81.0 \mathrm{ds}$ & 0 & 98 & 2 \\
\hline 2 & Mar. 1998 & 59 & 27.8 & $28.0 \mathrm{ds}$ & 10.2 & $22.0-35.2$ & $33.9 \mathrm{ds}$ & 2 & 98 & 0 \\
\hline 4 & Oct. 1997 & 85 & 31.8 & $31.0 \mathrm{ds}$ & 9.9 & $23.4-42.0$ & $57.6 \mathrm{~ns}$ & 21 & 79 & 0 \\
\hline 4 & Nov. 1997 & 67 & 32.9 & $32.0 \mathrm{ds}$ & 11.3 & $28.4-47$ & $53.7 \mathrm{~ns}$ & 5 & 95 & 0 \\
\hline 4 & Dic. 1997 & 20 & 32.7 & $33.0 \mathrm{~ns}$ & 6.6 & $29.0-37.6$ & $65.0 \mathrm{~ns}$ & 5 & 95 & 0 \\
\hline 4 & Ene. 1998 & 15 & 32.2 & $32.0 \mathrm{~ns}$ & 6.0 & $29.7-35.4$ & $80.0 \mathrm{ds}$ & 0 & 100 & 0 \\
\hline 4 & Feb. 1998 & 37 & 31.9 & $32.0 \mathrm{~ns}$ & 7.7 & $25.9-37.5$ & $75.7 \mathrm{ds}$ & 0 & 95 & 5 \\
\hline 4 & Mar. 1998 & 60 & 31.5 & $31.0 \mathrm{ds}$ & 5.8 & $28.5-37.6$ & $58.3 \mathrm{~ns}$ & 5 & 95 & 0 \\
\hline 4 & May. 1998 & 72 & 30.9 & $31.0 \mathrm{ds}$ & 8.3 & $27.0-37.2$ & $79.2 \mathrm{ds}$ & 0 & 0 & 100 \\
\hline 4 & Jun. 1998 & 76 & 30.5 & $30.0 \mathrm{ds}$ & 7.3 & $27.2-37.0$ & $48.7 \mathrm{~ns}$ & 0 & 0 & 100 \\
\hline 10 & Sep. 1997 & 18 & 35.1 & $34.5 \mathrm{ds}$ & 13.1 & $29.0-45.0$ & $55.6 \mathrm{~ns}$ & $* *$ & $* *$ & $* *$ \\
\hline 10 & Oct. 1997 & 21 & 30.3 & $30.0 \mathrm{ds}$ & 16.5 & $17.3-38.6$ & $57.1 \mathrm{~ns}$ & $* *$ & $* *$ & $* *$ \\
\hline 10 & Ene. 1998 & 34 & 32.9 & $32.5 \mathrm{ds}$ & 21.3 & $19.3-49.5$ & $73.5 \mathrm{ds}$ & $* *$ & $* *$ & $* *$ \\
\hline
\end{tabular}


El CV presentó cambios a lo largo del período de muestreo $\mathrm{y}$ sus valores fueron bajos en invierno y altos en verano. El aumento del CV para la talla, y las variaciones de la proporción de sexos entre los distintos artes, podrían estar más relacionados con la zona de operación del arte en relación al recurso objetivo, que con el aumento en el tamaño de la malla. Es probable que en los meses de verano la mezcla de distintos grupos de talla debido a la actividad reproductiva conduzca a los aumentos observados en el CV. En este sentido, en otras áreas se postulan cambios en la estructura de la población durante la época reproductiva para la corvina (Castello, 1986; Cousseau et al., 1986; Acuña et al., 1992; Norbis et al., 1992; Haimovici y Umpierre, 1996), estando de acuerdo con un patrón de comportamiento que frecuentemente es seguido por peces que realizan migraciones (Harden-Jones, 1968; Sparre et al., 1989). Los movimientos realizados por la corvina blanca en el Río de la Plata se asocian con factores ambientales relacionados con la reproducción (Macchi, 1997; Acha et al., 1999; Vizziano et al., 2001). Estos cambios se explican para la corvina en Laguna de Rocha por la preferencia de los individuos de tallas mayores por zonas más profundas y por el reclutamiento al arte de los juveniles que comienzan su proceso de maduración durante el verano. Debido a esto, en la zona donde operó la pesca dirigida a la lisa predominaron tallas mayores, y éstas se redujeron hacia el final del verano cuando se incorporaron los reclutas a la población reproductivamente activa. Si bien en Laguna de Rocha las diferencias de profundidad no son grandes $(\leq 1.4 \mathrm{~m})$, podrían existir ventajas para aquellos individuos que se ubican en profundidades mayores relacionadas con el ocultamiento de los depredadores, ya que la laguna cuenta con varias especies de aves acuáticas que se alimentan de peces (Azpiroz, 2001) y es probable que éstas sean menos eficaces en su captura en zonas más profundas (Paterson y Whitfield, 2000). A su vez, las corvinas de tallas menores podrían ser excluidas de las zonas más profundas debido a la competencia intraespecífica. Dado que la relación depredador-presa y la competencia no han sido estudiadas en Laguna de Rocha, la comprobación de esta hipótesis requeriría de estudios de ecología de comunidades en el área.

Durante la época de reproducción la proporción de sexos puede ser variable. En este trabajo, los sexos se presentaron en proporciones iguales o predominaron las hembras. En Laguna de los Patos (Brasil) las hembras predominaron sobre los machos (Castello, 1986) y en Río de la Plata sucede a la inversa (Acuña et al., 1992; Macchi et al., 1996). Considerando la información temporal obtenida con A1, el aumento de la proporción de hembras, junto con el aumento de la heterogeneidad de tallas, estaría sugiriendo que existen movimientos de diferentes grupos de tallas y segregación por sexo.

Teniendo en cuenta la talla de primera madurez calculada para la especie en la laguna (machos: $19.2 \mathrm{~cm}$; hembras: $20.4 \mathrm{~cm}$ ) (Vizziano et al., 2002), cada una de las pesquerías dirigidas afecta de manera distinta la estructura de la población durante la época de desove. La pesca dirigida al camarón (A1), que se realiza desde fines de febrero hasta fines de abril gear (A1) was used, to deeper and less coastal areas, where mullet is caught. These migrations of different size groups may reverse according to the season. The spatial segregation by size groups of M. furnieri has been reported for Río de la Plata and southern Brazil (Ehrhardt et al., 1977; Ehrhardt et al., 1979; Cousseau et al., 1986; Sánchez et al., 1991; Haimovici and Umpierre, 1996).

The CV varied throughout the study period, with low values in winter and high in summer. The increase in CV for size and the variation in the proportion of males and females among the different gear may be related more to the area in which the gear is used relative to the target species, than to the increase in mesh size. It is probable that during the summer months, the mixture of different size groups due to breeding activities leads to the increases in $\mathrm{CV}$ observed. Changes in the structure of the population during the breeding season have been reported for the croaker in other areas (Castello, 1986; Cousseau et al., 1986; Acuña et al., 1992; Norbis et al., 1992; Haimovici and Umpierre, 1996), which concurs with a pattern of behaviour often followed by migratory fishes (HardenJones, 1968; Sparre et al., 1989). The movements of the white croaker at Río de la Plata are associated with environmental factors related to reproduction (Macchi, 1997; Acha et al., 1999; Vizziano et al., 2001). At Rocha Lagoon, these changes are explained by the preference of the larger individuals for deeper zones and the recruitment to the fishery of the juveniles beginning their maturation process in the summer. Therefore, in the fishing area where mullet is targeted, the larger sizes predominated until the end of summer, when the recruits joined the reproductively active population. Even though the differences in depth are not large at Rocha Lagoon $(\leq 1.4 \mathrm{~m})$, there may be advantages for those individuals that seek deeper depths as protection from predators, since several fish-eating aquatic birds are found at this lagoon (Azpiroz, 2001) that are probably less successful in catching their prey in deeper zones (Paterson and Whitfield, 2000). On the other hand, the smaller-sized croakers may be excluded from the deeper areas because of intraspecific competition; however, as predator-prey relationships and competition have not been studied at Rocha Lagoon, community ecology studies are required to verify this hypothesis.

During the breeding season, the proportion of sexes can vary. In this work, the male to female ratio was equal or the females predominated. Females were more predominant than males at Patos Lagoon (Brazil), whereas males predominated at Río de la Plata (Acuña et al., 1992; Macchi et al., 1996). In view of the temporal information obtained with A1, the increase in the proportion of females together with the increase in size heterogeneity suggests that there are movements of different size groups and segregation by sex.

Considering the size at first maturity calculated for the species at the lagoon (males: $19.2 \mathrm{~cm}$; females: $20.4 \mathrm{~cm}$ ) (Vizziano et al., 2002), each of the fisheries affects the population structure during the spawning season in a different way. The shrimp fishery (A1), conducted from late-February to 
(Norbis, 2000), coincide con el final del período de reproducción de la corvina (Vizziano et al., 2002) y afecta individuos apenas por encima de la talla de primera madurez. Sin embargo, las otras pesquerías capturan individuos que superan en varios centímetros la talla de primera madurez. Desde 1997 la modalidad operativa dirigida a la pesca del camarón cambió al uso de las trampas (Norbis, 2000) y el efecto sobre los desovantes de corvina blanca debería ser menor.

Los individuos mayores de $40 \mathrm{~cm}$ fueron escasos y posiblemente dejan la laguna en busca de otras áreas de reproducción y alimentación en los momentos en que la apertura de la barra puede permitir el intercambio de individuos (Castello, 1986; Hozbor y García de la Rosa, 2000).

Los pescadores artesanales de Laguna de Rocha basan su economía de subsistencia en la explotación de diversos recursos acuáticos y cada una de las pesquerías dirigidas dependen de la disponibilidad del recurso y demanda del mercado. La corvina blanca es capturada como fauna acompañante y algunas veces se utiliza para consumo familiar. Laguna de Rocha constituye un área de reproducción para la corvina blanca (Vizziano et al., 2002). A excepción de la pesquería orientada al camarón, el resto capturó individuos varios centímetros por encima de la talla de inicio de madurez calculada para la especie en la laguna. Futuros trabajos deberán tener en cuenta información sobre esfuerzo y captura de cada pesquería para poder determinar el impacto sobre los individuos desovantes, información básica para la conservación y manejo de uno de los recursos pesqueros del Parque Nacional.

\section{Agradecimientos}

Se agradece a PROBIDES (Programa de Conservación de la Biodiversidad y Desarrollo Sustentable en los Humedales del Este, proyecto URU/97/G31 PNUD-GEF-MVOTMA) por financiar, junto con Facultad de Ciencias (Universidad de la República Oriental del Uruguay), este estudio y por brindar su apoyo logístico. A los pescadores residentes de Laguna de Rocha: Justo Vicente Ballesteros, Blanca Seijas, José Luis, Jorge, Santiago y Mariana Ballesteros; Fabián y Lucy Huelmo; Ángel Álvarez; Walter Fernández; que hicieron posible con su trabajo la obtención del material biológico. Además, hacemos extensivo el agradecimiento a Pablo Meneses por el diseño de la figura $1 \mathrm{y}$ a todos los estudiantes que colaboraron con los muestreos.

\section{Referencias}

Acuña, A., Verocai, J. y Márquez, S. (1992). Aspectos biológicos de Micropogonias furnieri (Desmarest, 1823) durante dos zafras en una pesquería artesanal al oeste de Montevideo. Rev. Biol. Mar., 27(1): 113-132.

Acha, E.M., Mianzan, H., Lasta, C.A. and Guerrero, R.A. (1999). Estuarine spawning of the whitemouth croaker Micropogonias furnieri (Pisces: Sciaenidae), in the Río de la Plata, Argentina. Mar. Freshwater Res., 50: 57-65.
late-April (Norbis, 2000), coincides with the end of the croaker's breeding season (Vizziano et al., 2002), and affects individuals slightly larger than the size at first maturity; however, other fisheries capture individuals several centimeters larger than the size at first maturity. In 1997, the modality of operation in the shrimp fishery changed to the use of traps (Norbis, 2000), which should have less of an effect on the spawners.

Individuals larger than $40 \mathrm{~cm}$ were scarce and possibly leave the lagoon in search of other breeding and feeding areas when the mouth opens and permits the exchange of individuals (Castello, 1986; Hozbor and García de la Rosa, 2000).

The artisanal fishermen at Rocha Lagoon base their subsistence economy on the exploitation of diverse aquatic resources and each fishery depends on the availability of the resource and market demand. Rocha Lagoon is a breeding area for the white croaker (Vizziano et al., 2002), which is caught as bycatch and is sometimes used for local consumption. Except for the shrimp fishery, the other fisheries capture individuals several centimeters larger than the size at first maturity calculated for this species at the lagoon. Future studies should consider catch and effort data for each fishery to determine the impact on the spawning individuals and obtain information for the conservation and management of one of the fishery resources of the national park.

\section{Acknowledgements}

We thank PROBIDES (Programa de Conservación de la Biodiversidad y Desarrollo Sustentable en los Humedales del Este, project URU/97/G31 PNUD-GEF-MVOTMA) and the Facultad de Ciencias of the Universidad de la República Oriental del Uruguay for financial and logistic support of this study. We are grateful to the resident fishermen and women at Rocha Lagoon whose work enabled us to obtain the biological material: Justo Vicente Ballesteros; Blanca Seijas; José Luis, Jorge, Santiago and Mariana Ballesteros; Fabián and Lucy Huelmo; Angel Alvarez; and Walter Fernández. Finally, we thank Pablo Meneses who designed figure 1 and all the students who collaborated with the samplings.

English translation by Christine Harris.

Arena, G.J. (1990). Evaluación de la captura máxima sostenible de la corvina blanca (Micropogonias furnieri) presente en el área operativa de la flota uruguaya, mediante modelos de producción excedente. Frente Marítimo, 7(A): 25-35.

Azpiroz, A. (2001). Aves del Uruguay. Lista e Introducción a su Biología y Conservación. Aves. Uruguay-GUPECA. Graphics Editorial, Montevideo, Uruguay, 105 pp.

Castello, J.P. (1986). Distribución, crecimiento y maduración sexual de la corvina juvenil (Micropogonias furnieri) en el estuario de la "Laguna dos Patos", Brasil. Physis, 44(106): 21-36.

Conde, D. and Sommaruga, R. (1999). A review of the state of limnology in Uruguay. In: R.G. Wetzel and B. Gopal (eds.), Liomnology in Developing Countries. New Dehli: SIL/ International Sciences Publ., pp. 1-31. 
Cousseau, M.B., Cortina, C.P., Cordo, H.D. y Burgos, G.E. (1986). Análisis de datos biológicos de corvina rubia (Micropogonias furnieri) y pescadilla de red (Cynoscion striatus) obtenidos en dos campañas del año 1983. Publicación de la Comisión Técnica Mixta del Frente Marítimo, 1(2): 319-332.

Csirke, J. (1980). Introducción a la dinámica de poblaciones de peces. FAO, Documento Técnico de Pesca, 192: 82 pp.

Ehrhardt, N., Arena, G., Abella, A., Varela, Z., Sánchez, E., Ríos, C. y De Moratorio, N.B. (1977). Evaluación preliminar de los recursos demersales en el área común de pesca argentino-uruguaya. 19751976. INAPE. Informe Técnico, Montevideo, 11: 176 pp.

Ehrhardt, N., Arena, G., Abella, A., Ríos, C. y De Moratorio, N. (1979). Evaluación preliminar de los recursos demersales en la Zona Común de Pesca Argentino-Uruguaya. 1977. INAPE. Informe Técnico, Montevideo, 13: 186 pp.

Haimovici, M. (1998). Present state and perspectives for the southern Brazil shelf demersal fisheries. Fish. Manage. Ecol., 5: 277-289.

Haimovici, M. y Umpierre, R.G. (1996). Variaciones estacionales en la estructura poblacional del efectivo pesquero de corvina blanca Micropogonias furnieri (Desmarest, 1823) en el extremo sur de Brasil. Atlántica, 18: 179-203.

Harden-Jones, F.R. (1968). Fish Migration. Edward Amold, London, $325 \mathrm{pp}$.

Hozbor, N.M. y García de la Rosa, S.B. (2000). Alimentación de juveniles de corvina rubia (Micropogonias furnieri) en la Laguna Costera Mar Chiquita (Buenos Aires, Argentina). Frente Marítimo, 18(A): 59-70.

Isaac-Nahum, V.J. (1988). Synopsis of biological data on the whitemouth croaker, Micropogonias furnieri (Desmarest, 1823). FAO, Fisheries, 150: $35 \mathrm{pp}$.

Lucena, F.M. and O'Brien, C.M. (2001). Effects of gear selectivity and different calculation methods on estimating growth parameters of bluefish, Pomatomus saltatrix (Pisces: Pomatomidae), from southern Brazil. Fish. Bull., 99: 432-442.

Macchi, G.J. (1997). Reproducción de la corvina rubia (Micropogonias furnieri) del sector rioplatense. Su relación con los gradientes horizontales de salinidad. Rev. Investigación y Desarrollo Pesquero. 11: 73-94.

Macchi, G.J., Acha, M.E. y Lasta, C.A. (1996). Desove y fecundidad de la corvina rubia Micropogonias furnieri Desmarest, 1823 del estuario del Río de la Plata, Argentina. Bol. Instituto Español de Oceanografía, 12(2): 99-113.

Millar, R.B. and Fryer, R.J. (1999). Estimating the size-selection curves of towed gears, traps, nets and hooks. Rev. Fish Biol. Fish., 9: 89-116.

Nédélec, C. and Prado J. (1990). Definición y clasificación de las diversas categorías de artes de pesca. FAO, Documento Técnico de Pesca, 222: 92 pp.
Norbis, W. (2000). Estudio sobre la población de camarón rosado (Penaeus paulensis) en las lagunas costeras de la Reserva de la Biosfera Bañados del Este. PROBIDES, Uruguay. Documento de Trabajo No. 28, 40 pp.

Norbis, W., Paesch, L., Verocai, J. y Villamarín, G. (1992). Cambios en la estructura de la población de corvina (Micropogonias furnieri) capturada en la pesquería artesanal de Pajas Blancas, Montevideo, Uruguay. Frente Marítimo, 11(A): 37-45.

Paterson, A.W. and Whitfield, A.K. (2000). Do shallow-water habitats function as refugia for juvenile fishes? Estuar. Coast. Shelf Sci., 51: 359-364.

Pintos, W., Conde, D., De León, R., Cardezo, M.J., Jorcinm, A. and Sommaruga, R. (1990). Some limnological characteristics of Laguna de Rocha (Uruguay). Rev. Brasileira de Biologia, 51(1): 79-84.

Reis, E.G. and Pawson, M.G. (1999). Fish morphology and estimating selectivity by gillnets. Fish. Res., 39: 263-273.

Sampson, D.B. and Al-Jufaily, S.M. (1999). Geographic variation in the maturity and growth schedules of English sole along U.S. west coast. J. Fish Biol., 54: 1-17.

Sánchez, F., Mari, N., Lasta, C. y Giangiobbe, A. (1991). Alimentación de la corvina rubia (Micropogonias furnieri) en la Bahía Samborombon. Frente Marítimo, 8(A): 43-50.

Santana, O. y Fabiano, G. (1999). Medidas y mecanismos de administración de los recursos de las lagunas costeras del litoral Atlántico del Uruguay (Lagunas José Ignacio, Garzón, de Rocha y de Castillos). Plan de Investigación Pesquera, INAPE-PNUD URU/92/003. $169 \quad$ pp. (http://www.dinara.gub.uy/ Publicaciones\%20-\%20Archivos\%20PDF/ Lagunas\%20costeras.pdf).

Sommaruga, R. y Conde, D. (1990). Distribución de materia orgánica en los sedimentos recientes de la Laguna de Rocha (Rocha, Uruguay). Atlántica, 12(1): 35-44.

Sparre, P., Ursin, E. and Venema, S.C. (1989). Introduction to tropical fish stock assessment. Part 1. Manual. FAO Fish. Tech. Paper, 306(1): $337 \mathrm{pp}$.

Vizziano, D., Saona, G., Franco, J. y Nagy, G.J. (2001). Caracterización ambiental del área de desove de la corvina blanca Micropogonias furnieri en la zona frontal del Río de la Plata. En: D. Vizziano, P. Puig, C. Mesones y G.J. Nagy (eds.), El Río de la Plata, Investigación para la Gestión del Ambiente, los Recursos Pesqueros y la Pesquería en el Frente Salino. Programa EcoplataUNESCO, Montevideo, pp. 115-128.

Vizziano, D., Forni, F., Saona, G. and Norbis, W. (2002). Reproduction of Micropogonias furnieri in a shallow temperate coastal lagoon in the southern Atlantic. J. Fish Biol., 61(A): 196206.

Zar, J.H. (1996). Biostatistical Analysis. Prentice Hall, New Jersey, $918 \mathrm{pp}$. 